Research paper

\title{
Linking upper Silurian terrestrial and marine successions-Palynological study from Skåne, Sweden
}

\author{
Kristina Mehlqvist* ${ }^{*}$, Kent Larsson, Vivi Vajda \\ Department of Geology, Lund University, Sölvegatan 12, SE-223 62 Lund, Sweden
}

\section{A R T I C L E I N F O}

\section{Article history:}

Received 27 May 2013

Received in revised form 31 October 2013

Accepted 2 December 2013

Available online 12 December 2013

\section{Keywords:}

early land-plants

Baltica

conodonts

chitinozoans

biostratigraphy

\begin{abstract}
A B S T R A C T
We have performed a palynostratigraphic study on miospore assemblages from near-shore marine Silurian sedimentary rocks of Skåne, southern Sweden. The material includes both drillcore (from Klintaborrningen 1 and Bjärsjölagårdborrningen 2) and outcrop samples from various localities in Skåne. Well- preserved spore assemblages were identified. Long ranging species with a global distribution dominate the spore assemblages, including Ambitisporites sp., Dyadospora sp., Laevolancis sp., and Tetrahedraletes sp. and complemented with key taxa including Emphanisporites neglectus, Hispanaediscus lamontii, Hispanaediscus verrucatus, Scylaspora scripta, Synorisporites libycus and Synorisporites tripapillatus. Based on biostratigraphical schemes for early land plant spores, the studied sedimentary rocks of the cores Klintaborrningen 1 and Bjärsjölagårdborrningen 2 are interpreted as late Silurian in age, spanning Ludlow to Prídolí. The spore assemblages are compared and correlated to marine fossil schemes including those of conodonts, chitinozoans, graptolites and tentaculitids. Additionally, relative abundance data of specific spore taxa have been used for correlation between the drillcores and the outcrops.
\end{abstract}

(c) 2013 Elsevier B.V. All rights reserved.

\section{Introduction}

Several localities exposing Silurian sedimentary rocks occur in Sweden and many of them are situated in Skåne, southern Sweden. The exposed successions range in age from Llandovery to Príidolí (Grahn, 1996). However, many of the outcrop sections are inaccessible today. Over the years these sedimentary rocks have been studied in many aspects, especially with focus on the marine biota and the lithostratigraphic distribution. Whilst there are a vast number of studies on different groups of marine organisms (see next section), none- or very little data exist on the late Silurian terrestrial biota of Sweden (Hagström, 1997; Hagström and Mehlqvist, 2012; Mehlqvist et al., 2012).

This study aims to shed light on the previously poorly investigated Silurian spore assemblages from Sweden and to correlate subsurface samples with exposed Silurian strata. The aim of this paper is to link the marine and terrestrial microfossil assemblages in order to improve the stratigraphical framework for this geographical area by combining the new palynological data with previously published data on marine biota. Our results provide the first palynostratigraphical correlation of upper Silurian strata between outcrops and drillcores in Sweden and provide, for the first time a tie between marine and terrestrial biostratigraphical schemes.

\footnotetext{
* Corresponding author.

E-mail address: Kristina.Mehlqvist@geol.lu.se (K. Mehlqvist).
}

\section{Previous works}

Numerous stratigraphic and taxonomic studies have been carried out on marine microfossils from Swedish Silurian strata, both from Gotland and Skåne which have led to one of the best resolved Silurian stratigraphical schemes in the world. Larsson (1979) studied the tentaculitids from Gotland and from the Öved-Ramsåsa Group in Skåne, shedding light not only on the taxonomy of this group, adding both to the knowledge on tentaculitids and their morphological variations, their palaeoenvironmental requirements but also on their stratigraphical occurrence in Swedish Silurian strata. Grahn (1996) described the chitinozoan assemblages from the Colonus Shale and the Öved-Ramsåsa Group in Skåne and erected a biostratigraphical scheme based on late Silurian chitinozoans. Conodont assemblages from the Öved-Ramsåsa Group in Skåne have been extensively studied and presented by Jeppsson (1974) and Jeppsson and Laufeld (1986) where a Ludlow to Přídolían age was inferred for the Öved-Ramsåsa Group Jeppsson and Laufeld (1986). Stratigraphical and taxonomical data based on Silurian conodont assemblages from Gotland were further presented by Jeppsson (2005) and Jeppsson et al. (2007). Eriksson et al. (2004) and Eriksson (2001) present data on Silurian scolecodonts from Gotland, and from Skåne (Eriksson, 2002). Nilsson (2002) focussed on graptolites from lower Ludlow strata in Skåne, southern Sweden and dated several localities using graptolite biostratigraphy. Vergoossen $(1999,2002 a, 2002 b, 2003,2004)$ included extensive taxonomic and stratigraphic results based on fish scales from upper Silurian deposits from the Öved Sandstone Formation of the Öved-Ramsåsa 
Group in Skåne, Sweden. From coeval assemblages on Gotland, late Silurian acritarchs and prasinophytes and their stratigraphic distribution have been described by Le Hérissé (1989). Additionally, Le Hérissé et al. (2009) described the biodiversity of phytoplankton such as acritarchs and prasinophytes from the late Silurian to the earliest Devonian from a global perspective. These studies have together greatly improved global Silurian stratigraphical schemes.

Data on the late Silurian terrestrial biota of Sweden are however very scarce and, as a matter of fact, data on terrestrial palynology from Baltica are even rarer. The few studies include Gray et al. (1974) who completed the first study on fossil spores from Sweden (Gotland and Skåne), mainly with a palaeoenvironmental angle, describing spores of early land plants. New data were presented more than 20 years later by Steemans (1996) and Hagström (1997) on spore assemblages based on a limited number of samples from the upper Silurian Burgsvik Formation, Gotland. Subsequently, Hagström and Mehlqvist (2012) described plant fossils with in situ cryptospores from the Burgsvik Beds from Gotland. New palynological investigations on Silurian material from Skåne, southern Sweden were initiated in 2008 as part of a Master's thesis (Mehlqvist, 2009) which resulted in the publication Mehlqvist et al. (2012) describing the taxonomical composition of the palynological assemblages of the two drillcores Klintaborrningen 1 and Bjärsjölagårdborrningen 2. Extensive work has, however, been performed on Silurian and Devonian spore assemblages from the British Isles that belonged to the palaeocontinent Avalonia at the time (e.g. Richardson and Lister, 1969; Wellman, 1993; Wellman and Richardson, 1993; Wellman et al., 2000). These assemblages are welldescribed and further work is needed to assess the similarities and differences between the assemblages of Avalonia and Baltica.

\section{Geological setting}

During the Silurian the palaeocontintents Baltica, Avalonia and Laurentia were located in the tropical climate zone at a low latitudinal position, south of the equator (Moore et al., 1994; Scotese, 2003; Fig. 1). The palaeocontinent Gondwana was located much further south of the equator, separated from Baltica by the Rheic Ocean and even reaching the South Pole (Cocks and Torsvik, 2002). At 440 Mya, Baltica collided with Avalonia and a combined landmass was formed. This combined landmass subsequently collided with Laurentia about 425 to 420 Mya and created the supercontinent Laurasia (Cocks and Torsvik, 2002). Based on palaeomagnetic data, Laurasia then drifted southwards and underwent counter-clockwise rotation (Cocks and Torsvik, 2002).

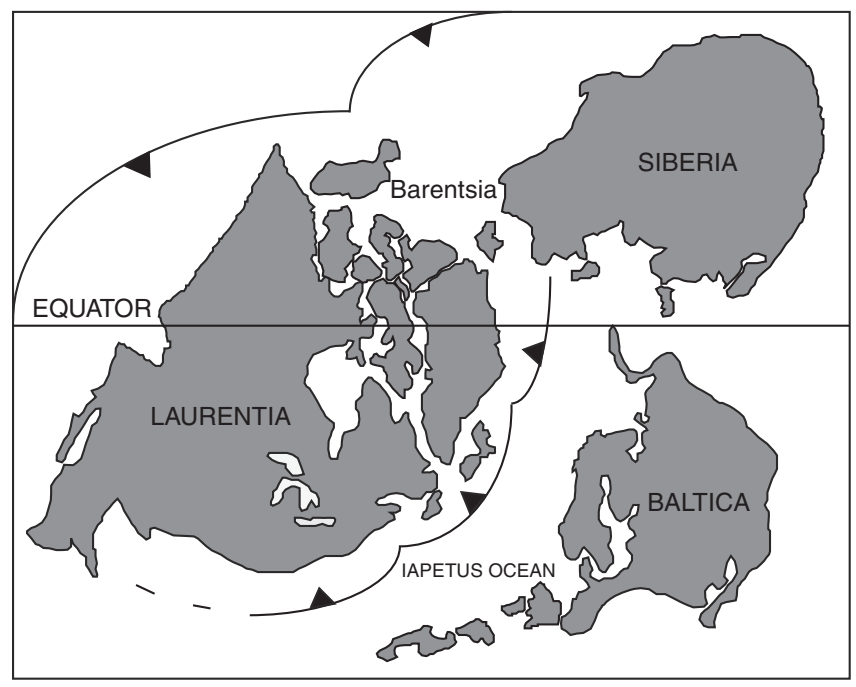

Fig. 1. Reconstruction of late Silurian palaeogeography showing the position of Baltica. Modified from http://www.scotese.com/.
During the Silurian Baltica was partly covered by an epicontinental sea and Silurian deposits have been identified in Norway, mid- and south Sweden, the Baltic Sea (Fig. 2a), the East Baltic States, Denmark and Poland (Jeppsson and Laufeld, 1986). The Silurian strata in Skåne reflect a gradual shallowing-up succession from deepwater graptolitic shales to shallow marine limestones and sandstones, and the sedimentary rocks are divided into the lower and middle Silurian Kallholn Formation, the Cyrtograptus Shale, the Colonus Shale and the upper Silurian Öved-Ramsåsa Group (Fig. 4) (Larsson, 1979; Jeppsson and Laufeld, 1986; Bergström et al., 1999; Märss et al., 1995; Melchin et al., 2004; Verniers et al., 2008).

Based on biostratigraphy of various marine fossil groups from exposed sedimentary rocks, the Öved-Ramsåsa Group has been dated to span Ludlow (Ludfordian stage) to Přídolí and include thereby the youngest Palaeozoic strata in Skåne (Jeppsson and Laufeld, 1986). The Öved-Ramsåsa Group is divided into the Klinta and the Öved Sandstone formations and the former is subdivided into the Lunnarna, Bjär, Bjärsjö and Bjärsjölagård Members (Jeppsson and Laufeld, 1986). Exposures of the Öved-Ramsåsa Group can be found in Klinta, Lunnarna, Bjärsjölagård and Ramsåsa (Fig. 2b).

The Öved-Ramsåsa Group is dominated by mudstones, in places tidally influenced, inter-layered with shallow marine carbonates (Wigforss-Lange, 1999, 2007). The sedimentary rocks of the Klinta Formation consist of mudstones interlayered with silt- and limestones. In the Bjärsjölagård Member, which is dominated by limestone, a thick carbonate unit (i.e. the Bjärsjölagård Limestone) occurs, overlain by a sandstone (The Öved Sandstone Formation) present in the Klinta, Bjärsjölagård and Ramsåsa areas (Jeppsson and Laufeld, 1986).

\section{Material and methods}

Two drillcores, Klintaborrningen 1 (K1) and Bjärsjölagårdborrningen 2 (B2), spanning the upper Silurian Öved-Ramsåsa Group in Skåne were sampled for palynology (Tables 1 and 2). Additionally, a range of exposures of Silurian age all over Skåne from the Colonus Shale and ÖvedRamsåsa Group were sampled in order to tie in the exposed successions with those from the drillcores. The exposed sections include Råröd 1, Lunnarna 1, Skarhult 1, Rövarkulan 1, Harlösa 1, Bjärsjölagård 2, Bjärsjölagård sandstone, Vollsjö 1, Järrestadsån 2 and Skillinge 2 (Fig. 2a; Table 3). These localities are described in the Results section. Altogether 78 samples were selected for palynological analysis for this study. The samples were processed according to standard palynological procedures at Global GeoLab Ltd., Alberta, Canada (see Mehlqvist et al., 2012 for more detailed description). A minimum of 150 specimens per slide were counted and identified taxonomically by light- and scanning electron microscope (SEM), and after the count of 150 was reached, the entire slide was further studied for rare taxa. In slides containing less than 150 spores, all the spores in the slide were counted. The taxonomical descriptions of the spores identified in the two drillcores were presented in Mehlqvist et al. (2012). Palynological slides and macerated residues are deposited at the Department of Geology, Lund University, Sweden.

\subsection{Stratigraphical schemes applied in this study}

For this study, a combination of the following spore zonations have been applied: Richardson and McGregor (1986), Richardson and Edwards (1989), Burgess and Richardson (1995), Richardson (1996) and Richardson et al. (2001). We have further applied the variation in abundance of specific taxa for correlation between the studied sections. The biostratigraphical zonations of Richardson and McGregor (1986) were based on assemblages from the Old Red Sandstone continent (Avalonia, Baltica and Laurentia). Richardson and Edwards (1989) refined the spore zonation of Richardson and McGregor (1986) to include three new zones spanning the entire Silurian up to Upper Devonian. Burgess and Richardson (1995) erected a sporomorph zonation 
a

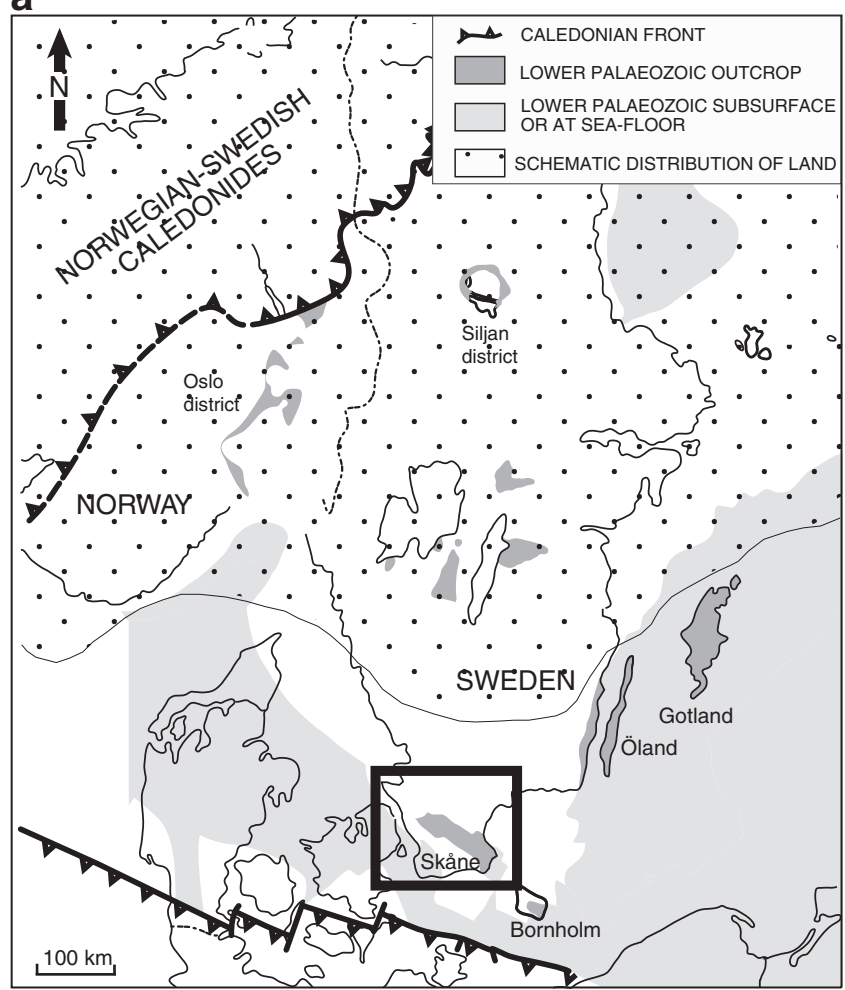

b

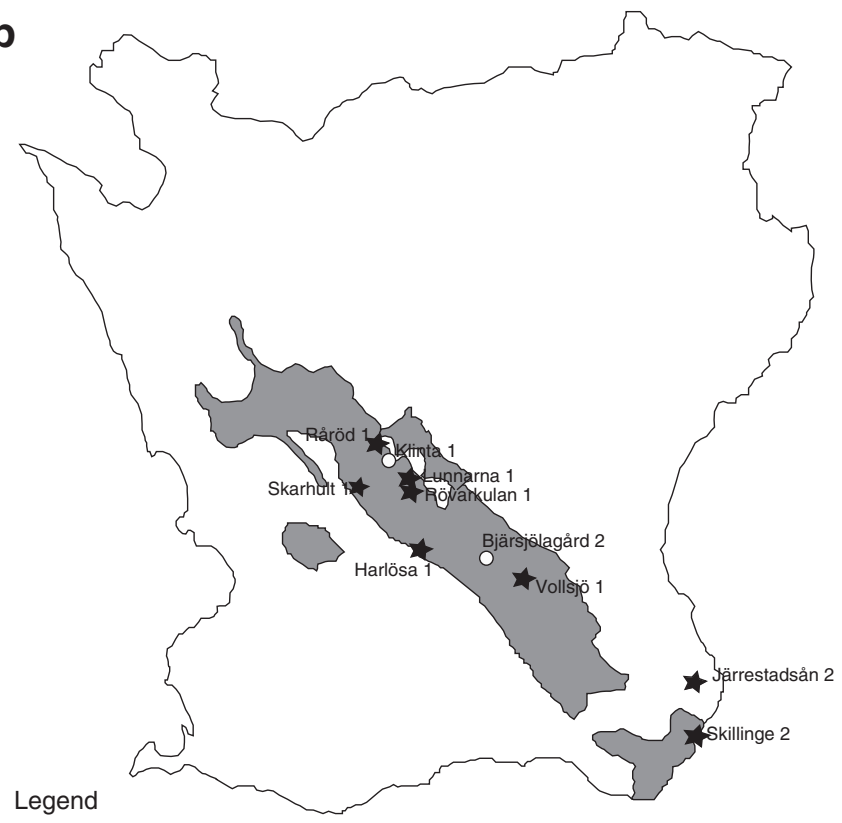

Silurian sediments

Outcrop locality

Borehole

Fig. 2. a. Map showing the extension of Silurian landmass (dotted pattern), superimposed on modern map of Scandinavia. Distribution of lower Palaeozoic rocks indicated by grey filling. The study area is marked. Map modified after Nielsen, 2004. b. Geological map of the study area with localities for the drillcores marked with circles, sampled exposures with stars.

including four zones and seven subzones for the Homerian to lower Přídolí, based on spore assemblages from successions in the AngloWelsh Basin, British Isles. A year later, Richardson (1996) defined seven phases of major sporomorph evolutionary events through the Cambrian to Upper Devonian. More recently, Richardson et al. (2001) constructed a biozonation based on spores from southern Britain and the Cantabrian Mountains in northern and northwestern Spain.

In our study, existing marine and terrestrial micropalaeontological zonation schemes are tied in with our palynological results. Linking the marine and terrestrial realms will not only provide improved stratigraphical control but will also provide time equivalent comparisons between marine and terrestrial palaeoenvironments during the studied interval.

\section{Results-palynology and stratigraphical implications}

\subsection{General composition of the spore assemblages}

The results from this study reveal rich and well preserved palynological assemblages and 36 spore species belonging to 21 genera were identified. The cryptospores are represented by 18 species, and the trilete spores by 18 species. The organic matter is highly dominated by spores and plant debris but marine microfossils, such as prasinophytes, acritarchs, chitinozoans and scolecodont elements occur in some samples. We further identified fungal spores and hyphae in a few samples together with tubular structures of an uncertain affinity but these are discussed elsewhere.

The sedimentary rocks from Råröd 1, Vollsjö 1 and Järrestadsån 2 outcrops are mostly dominated by long-ranging cosmopolitan species, mainly indicative of a mid Silurian age (e.g. Wenlock) but the dearth of biostratigraphically-important species makes a more detailed age estimation difficult (Table 3). Palynostratigraphical interpretations were hampered by low, or no spore recovery in samples from the following sites; Skarhult 1, Lunnarna 1, Harlösa 1, Skillinge 2, Rövarkulan 1 (Table 3).

\subsection{Drillcores}

\subsubsection{Klintaborrningen 1}

The sedimentary rocks in $\mathrm{K} 1$ are, based on the spore assemblages, dated to span Ludlow to Přídolí age (Fig. 3). The assemblage is strongly dominated by cryptospores but the relative abundance of trilete spores increases upwards. Laevolancis plicata is the dominant species (Table 1) followed by Laevolancis divellomedia (Fig. 5; Plate I:7). Most of the succession belongs to the libycus-poecilomorphus Assemblage Zone of Richardson and McGregor (1986) and miospore Zone 4B to 5A of Richardson (1996); Figs. 3-4, based on the occurrence of the species Emphanisporites neglectus together with Synorisporites cf. libycus and apiculate spores such as Apiculiretusispora sp. indicative of a Ludlow age (Fig. 4). A late Silurian (late Ludlow to Přídolí) age is suggested for the topmost part of the Klintaborrningen 1 core based on the first occurrence of Synorisporites tripapillatus (Figs. 3-4). This corresponds to the Miospore Zone 5B of Richardson (1996) and to the Synorisporites tripapillatus-Apiculiretusispora spicula Assemblage Zone of Richardson and McGregor (1986). However, S. tripapillatus has been identified in Ludlovian successions (Rubinstein and Steemans, 2002) and these authors argue that $S$. tripapillatus alone is not necessarily indicative of Přídolí age but rather late Ludlow to early Přídolí.

In summary, these results show that the sedimentary rocks of the Klintaborrningen 1 core cover a time interval from Ludlow to early Přídolí (Figs. 3-4). One specimen of Chelinospora hemiesferica indicative of early to middle Príidolí (Richardson et al., 2001) was encountered in the lower part of the core (sample $5 ; 193 \mathrm{~m}$ ). However, as this single specimen is not consistent with the rest of the palynoflora of the Klintaborrningen 1 assemblage, its occurrence is herein interpreted as a down-core contamination during the drilling process although revealing that Př́idolí indeed is represented higher up in the succession.

The sedimentary rocks of the Klintaborrningen 1 are assigned to Saetograptus fritschi linearis-Saetograptus leintwardinensis to 


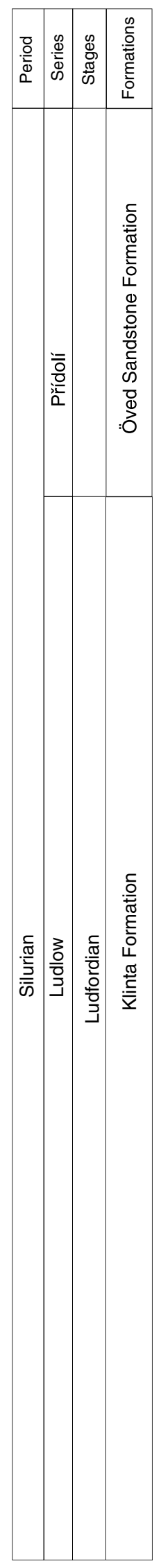

\section{Klintaborrningen 1 \\ Depth (m) Sample levels}

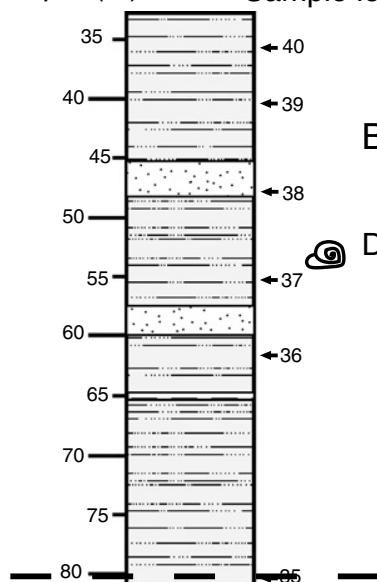

Bjärsjölagårdborrningen 2

Depth $(m) \quad$ Sample levels
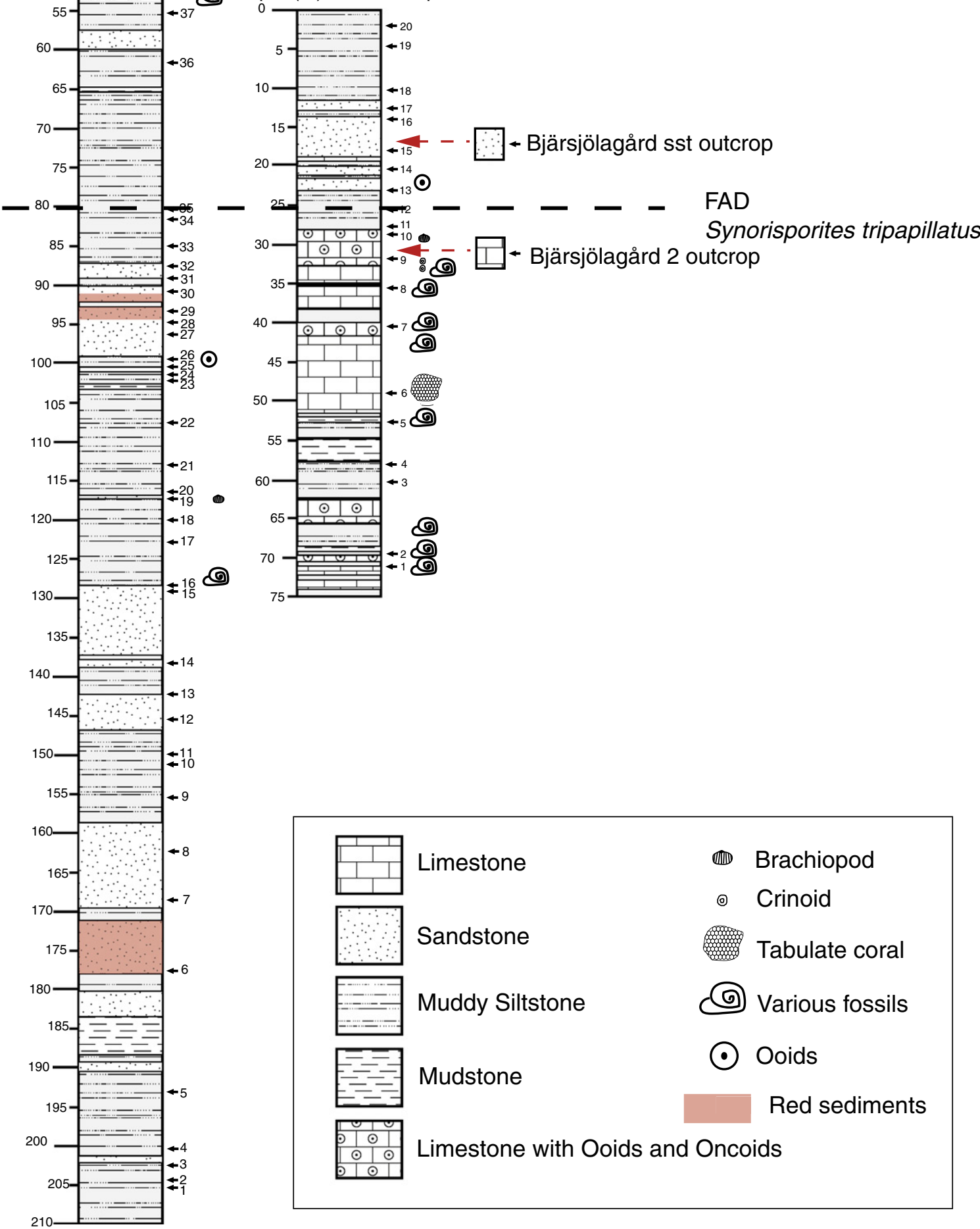

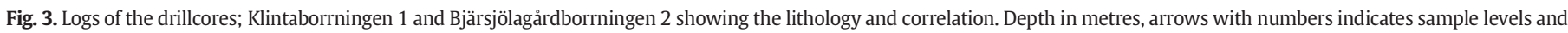
sample numbers. 
Table 1

Quantitative palynological data for the samples in the drillcore Klintaborrningen 1.

\begin{tabular}{|c|c|c|c|c|c|c|c|c|c|c|c|c|c|c|c|c|c|c|c|c|c|c|c|c|c|c|}
\hline Sample number & 1 & 2 & 3 & 4 & 5 & 6 & 8 & 9 & 10 & 12 & 13 & 17 & 19 & 20 & 21 & 22 & 23 & 24 & 25 & 27 & 35 & 36 & 37 & 38 & 39 & 40 \\
\hline $\begin{array}{l}\text { Taxa/depth } \\
\text { (m) }\end{array}$ & 205.31 & 204.98 & 202.20 & 200.89 & 193.09 & 178.24 & 156.37 & 153.41 & 151.76 & 143.33 & 138.83 & 122.96 & 117.42 & 116.28 & 112.28 & 107.71 & 103.58 & 101.95 & 100.45 & 96.02 & 80.12 & 61.62 & 55.11 & 47,91 & 40.03 & 35.90 \\
\hline Artemopyra radiata & 7 & 2 & & & 1 & & & & 1 & & & & & & & & & & & & & & & & & \\
\hline Cheilotetras caledonica & & 3 & 6 & 1 & 3 & 1 & & & & & & & & & & & & & & & & & 1 & & 1 & \\
\hline $\begin{array}{l}\text { Dyadospora murusdensa- } \\
\text { murusattenuata }\end{array}$ & 0 & 0 & 0 & 0 & 0 & 4 & 34 & 59 & 25 & 26 & 74 & 100 & 82 & 14 & 14 & 6 & 22 & 25 & 25 & 1 & 0 & 1 & & & 9 & 0 \\
\hline Hispanaediscus lamontii & 1 & & & & & & & & & & & & & & & & & & & & & & & & & \\
\hline Hispanaediscus verrucatus & & & & & & & & & & & & & & & & & 2 & & & & 1 & 1 & & & & \\
\hline Imperfectotriletes vavrdovae & & & 6 & 5 & 4 & & & & & & & & & & & & & & & & & 30 & 4 & & 12 & 2 \\
\hline $\begin{array}{l}\text { Laevolancis divellomedia- } \\
\text { plicata }\end{array}$ & 71 & 95 & 86 & 97 & 74 & 29 & 116 & 87 & 136 & 124 & 54 & 40 & 70 & 110 & 111 & 128 & 95 & 78 & 76 & 115 & 86 & 85 & 4 & 1 & 42 & 68 \\
\hline Rimosotetras problematica & & & & & & & & & & & & & & & & & & & & & & & & & 1 & 1 \\
\hline Tetrahedraletes grayii & 5 & & 2 & 1 & 3 & 8 & & & & & & & & & & & & & & & & 1 & & & & \\
\hline Tetrahedraletes medinensis & 57 & 44 & 23 & 20 & 13 & 84 & & 5 & & & 10 & 5 & 3 & 12 & 6 & 5 & 3 & 6 & 12 & 14 & 3 & 15 & 3 & & 11 & 25 \\
\hline Ambitisporites avitus-dilutus & 4 & 1 & 8 & 5 & 5 & 1 & 0 & 1 & 1 & 9 & 12 & 3 & 5 & 13 & 32 & 11 & 26 & 35 & 36 & 24 & 36 & 10 & 1 & 1 & 37 & 1 \\
\hline Ambitisporites parvus & & & & & & & & 2 & 1 & 1 & 1 & 1 & & & & & & & 1 & & & & & & & \\
\hline Amicosporites discus & & & & & 1 & & & & & & & & & & & & & & & & & & & & & \\
\hline $\begin{array}{l}\text { Apiculiretusispora? } \\
\text { burgsvikensis }\end{array}$ & 2 & 3 & 11 & 13 & 38 & 23 & & & 1 & & & 1 & & 1 & & & & 6 & & 1 & 1 & & & & & 25 \\
\hline $\begin{array}{l}\text { Archeozonotriletes chulus } \\
\text { morphon }\end{array}$ & 1 & & 6 & 7 & 6 & & & & & & & & & & & & & & & & & & 6 & 1 & 25 & 3 \\
\hline Chelinospora hemiesferica & & & & & 1 & & & & & & & & & & & & & & & & & & & & & \\
\hline Dictyotriletes sp. & & & & & & 1 & & & & & & & & & & & & & & & & & & & & \\
\hline Emphanisporites neglectus & & & & & & & & & 1 & & & & & & & & & & & & & & & & & \\
\hline Retusotriletes goensis & & & & & & & & & & & & & & & & & 1 & & & & & 1 & 6 & & & \\
\hline Retusotriletes cf. warringtonii & 4 & 3 & 1 & 1 & 2 & & & & & & & & & & & & & & & & & 6 & & & 14 & 7 \\
\hline Scylaspora klintaensis & & & & & & & & & & & & & & & 10 & & & & & & & & & & & 1 \\
\hline Scylaspora scripta & & & & & & 1 & & & & & & & & & & & & & & & & & & & & \\
\hline Synorisporites cf. libycus & & & & & & & & & & & & & & & & & & & & 3 & & & & & & \\
\hline Synorisporites tripapillatus & & & & & & & & & & & & & & & & & & & & & 11 & & & & & \\
\hline Synorisporites verrucatus & & & & & & 1 & & & & & & & & & & & & & & & & 1 & & & & 1 \\
\hline Total sum of spores counted & 152 & 151 & 149 & 150 & 151 & 153 & 150 & 154 & 166 & 160 & 151 & 151 & 163 & 151 & 173 & 150 & 150 & 150 & 150 & 158 & 138 & 151 & 25 & 3 & 152 & 134 \\
\hline
\end{tabular}


Table 2

Quantitative palynological data for the samples in the drillcore Bjärsjölagårdborrningen 2.

\begin{tabular}{|c|c|c|c|c|c|c|c|c|c|c|c|c|c|c|c|}
\hline Sample numbers & 2 & 3 & 4 & 5 & 6 & 9 & 10 & 11 & 12 & 13 & 14 & 15 & 18 & 19 & 20 \\
\hline $\begin{array}{l}\text { Taxa/depth } \\
(\mathrm{m})\end{array}$ & 69.65 & 60.72 & 57.94 & 52.93 & 48.83 & 31.9 & 28.9 & 27.55 & 25.3 & 23.11 & 20.34 & 17.97 & 10.03 & 4.73 & 2 \\
\hline Artemopyra rugaticosta & & 4 & & & & & & & & & & & & & \\
\hline Cymbohilates sp. A & & & 1 & 1 & & & & & & & & & & & \\
\hline Cymbohilates sp. B & & & 2 & 1 & 2 & 1 & & & 2 & & & & & & \\
\hline Dyadospora murusattenuata & 19 & 33 & 35 & 28 & 46 & 57 & 9 & 14 & 1 & 8 & 26 & & & 11 & 1 \\
\hline Dyadospora murusdensa & 33 & 23 & 32 & 41 & 34 & 55 & 11 & 14 & 17 & 23 & 23 & & 9 & 14 & 4 \\
\hline Hispanaediscus lamontii & & & & & & & & & & & & & 1 & & \\
\hline Hispanaediscus major & & & & & & & & & & & & & & 4 & \\
\hline Hispanaediscus verrucatus & & & & 1 & 2 & 4 & 5 & & 1 & 6 & & & 2 & 1 & \\
\hline Laevolancis divellomedia & 29 & 29 & 21 & 27 & 6 & 10 & 10 & 54 & 58 & 27 & 28 & 1 & 36 & 33 & 46 \\
\hline Laevolancis plicata & 24 & 31 & 42 & 42 & 31 & 15 & 18 & 37 & 37 & 59 & 28 & & 53 & 39 & 44 \\
\hline Rimosotetras problematica & & & & & & & & 1 & & & 1 & & 1 & & \\
\hline Tetrahedraletes grayii & & & & & & & & & & 1 & 2 & & & & \\
\hline Tetrahedraletes medinensis & 3 & 7 & 2 & 1 & 1 & 2 & 6 & 7 & 4 & 7 & 7 & & 9 & & 2 \\
\hline Ambitisporites avitus & 2 & 8 & 7 & 7 & 8 & & 15 & 9 & 17 & 9 & 15 & & 21 & 25 & 26 \\
\hline Ambititsporites dilutus & & 12 & 5 & 5 & 10 & 7 & 17 & 14 & 12 & 11 & 17 & & 11 & 18 & 18 \\
\hline Ambitisporites parvus & 2 & & & 1 & & & & & & & 1 & & 1 & & 1 \\
\hline Apiculiretusispora? burgsvikensis & 33 & & 1 & 1 & & & & & & & & & & 3 & \\
\hline Apiculiretusispora sp. A & & & & & 1 & & & & & & & & & 1 & \\
\hline Apiculiretusispora sp. B & & & 1 & & & & & & & & & & & & \\
\hline Emphanisporites neglectus & 1 & & & & & & & & & & & & 1 & & \\
\hline Retusotriletes goensis & 1 & 3 & 2 & & 1 & & & & 1 & & 2 & & 4 & 1 & \\
\hline Scylaspora scripta & & & & & & & & & & & 2 & & & & \\
\hline Synorisporites tripapillatus & & & & & & & & & 1 & & & & & & 3 \\
\hline Total sum of spores counted & 147 & 150 & 151 & 156 & 142 & 151 & 91 & 150 & 151 & 151 & 152 & 1 & 149 & 150 & 145 \\
\hline
\end{tabular}

Monograptus parultimus graptolite zones, as defined by Jaeger (1991), corresponding to the topmost part of the Angochitina echinataSphaerochitina sphaerocephala chitinozoan zone (Grahn, 1996; Fig. 4) and the Icriondontid-Ozarkodina crispa conodont zones (Jeppsson et al., 2006). These all indicate a Ludlow age for the sedimentary rocks (Fig. 3). It should be noted, however, that correlation to standard graptolite zones in post-leintwardinensis successions in Skåne must be considered tentative as diagnostic graptolites are very rare in the ÖvedRamsåsa Group.

The sedimentary rocks of the Klintaborrningen 1 are dominated by the cryptospore Laevolancis divellomedium morphon (Steemans, 1996), Dyadospora murusdensa-murusattenuata morphon (Steemans, 1996) and Ambitisporites avitus-dilutus morphon (Steemans, 1996), however significant changes in relative abundance are seen throughout the succession. The assemblages from the basal part of the core are dominated by Laevolancis divellomedium morphon, Tetrahedraletes medinensis, and by Apiculiretusispora? burgsvikensis reaching 25\% of the total spore content in sample 5. Taxa occurring in low portions within the basal part of the core include Artemopyra radiata, Scylaspora scripta and Synorisporites verrucatus (Fig. 5 and 6).

The assemblage in the middle part of the drill core is dominated by Dyadospora murusdensa-murusattenuata and Laevolancis divellomedium reaching maximum values of relative abundance of $66 \%$ and $85 \%$, respectively. Taxa occurring in low abundances comprise Emphanisporites neglectus, Scylaspora klintaensis and Retusotriletes goensis (Fig. 5).

The assemblage within the topmost part of the core shows prominent changes in that Ambitisporites avitus-dilutus increase significantly in abundance. Together with L. divellomedium they dominate. Hispanaediscus verrucatus, Tetrahedraletes medinensis, Retusotriletes goensis and Synorisporites spp. occur as minor components.

\subsubsection{Bjärsjölagårdborrningen 2}

A late Silurian (late Ludlow to Přídolí) age is suggested for the topmost part $(25.3 \mathrm{~m}-2 \mathrm{~m})$ of the Bjärsjölagårdborrningen 2 based on the first occurrence of Synorisporites tripapillatus (Figs. 3-4). This interval corresponds to the Synorisporites tripapillatus-Apiculiretusispora spicula Assemblage Zone of Richardson and McGregor (1986) and to the Miospore subphase 5B of Richardson (1996). The assemblage is dominated by the cryptospore species Laevolancis plicata, Dyadospora murusdensa, Dyadospora murusattenuata and Laevolancis divellomedia.

The sedimentary rocks from B2 are assigned to the Saetograptus fritschi linearis-Saetograptus leintwardinensis to Monograptus P. parultimus graptolite zones (Ludfordian to Př́idolí). This corresponds to the top of the Angochitina echinata up to Sphaerochitina sphaerocephala chitinozoan zone and to the Icriodontid-Ozarkodina crispa conodont zones (Fig. 4). These age assessments inferred from the marine microfossils agree perfectly with the age assessments of the spore assemblages from B2.

The dominant components i.e. Laevolancis divellomedium morphon and Dyadospora murusdensa-murusattenuata morphon reach top values of $100 \%$ and $70 \%$ respectively (Fig. 5). Ambitisporites avitus-dilutus varies in abundance between 10 and 35\% and peaks at c. $28 \mathrm{~m}$. Other spore taxa occurring in lower relative abundances include Hispanaediscus lamontii, Hispanaediscus major and Synorisporites tripapillatus (Fig. 5).

\subsection{Outcrop sections}

The outcrop samples are less diverse but dominated by the same longranging cryptospore species as in the assemblages from the drillcores. Additional spore taxa that are not encountered in the drillcore assemblages include; Pachytetras rugosa and Chelinohilates spp. Positions for the localities are given according to the reference system SWEREF 99TM.

\subsubsection{Early Ludlow-Gorstian}

5.3.1.1. Vollsjö 1. Dark mudstones belonging to the Colonus Shale are exposed along the Vollsjöån rivulet. An exposure in the rivulet was sampled below the old railway bridge close to Solgården (6173796 $\mathrm{N} / 423334 \mathrm{E}$ ). Only 10 spore taxa were identified in this single sample. The assemblage is dominated by Laevolancis divellomedia but also contains Laevolancis plicata, Tetrahedraletes medinensis, Ambitisporites avitus, Chelinohilates sp. and Tetrahedraletes grayii (Fig. 6). This assemblage shows a similar species composition as the sample from Råröd 1 , also dominated by the same long ranging species. Additionally, chitinozoans, scolecodont elements and acritarchs occur in the sample and these sedimentary rocks have previously been dated to Ludlow (Gorstian) and assigned to the Colonograptus colonus graptolite zone, corresponding to the top of Sphaerochitina lycoperdoides chitinozoan 


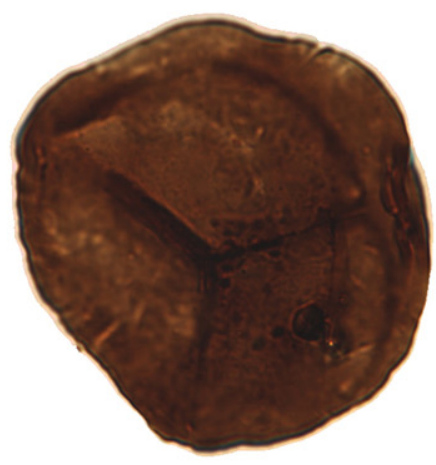

1

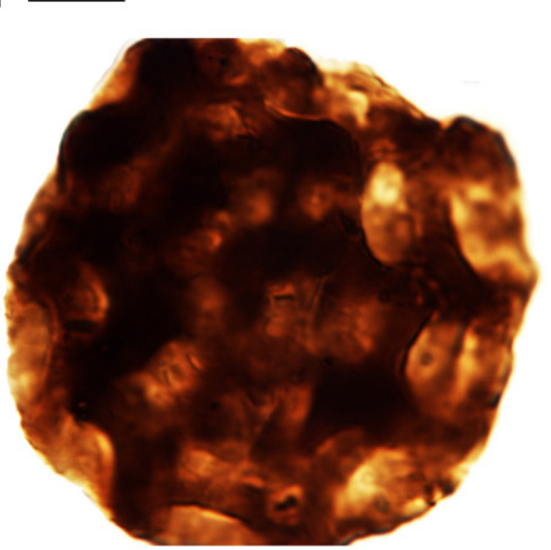

4

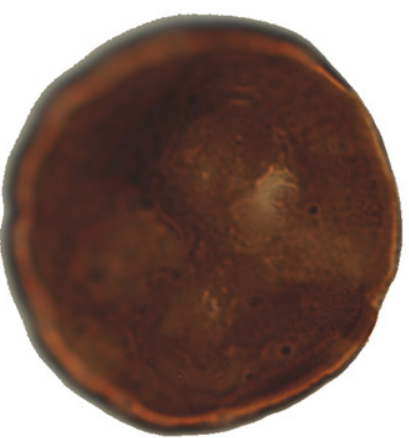

7

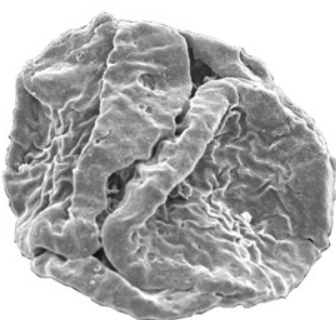

10

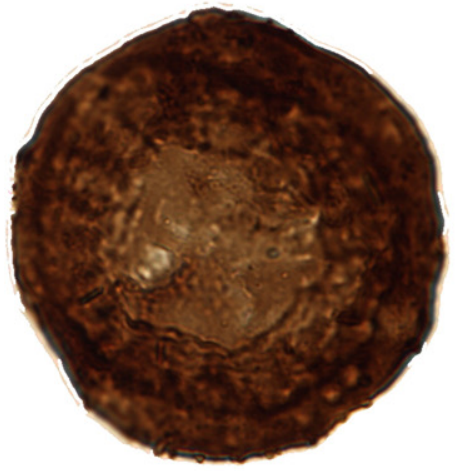

2

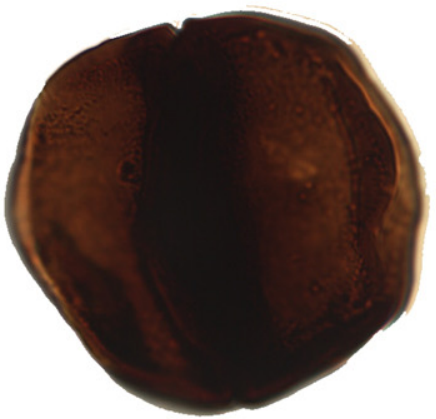

5
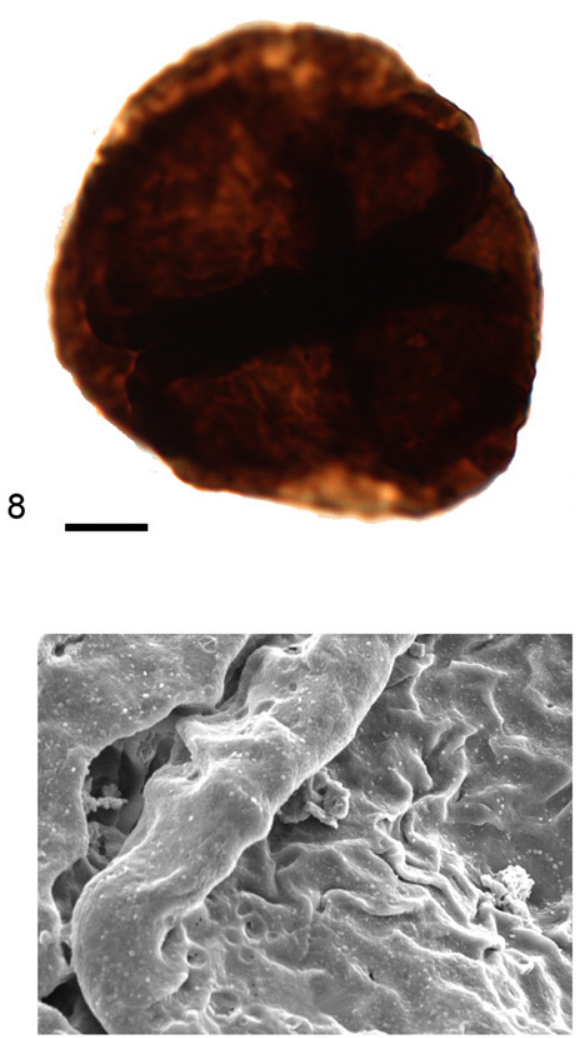

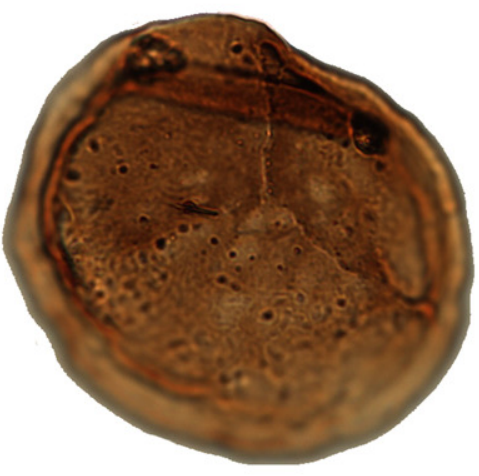

3

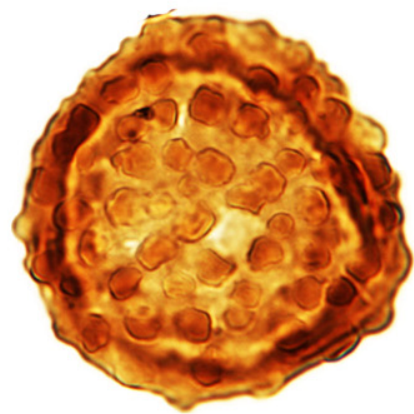

6
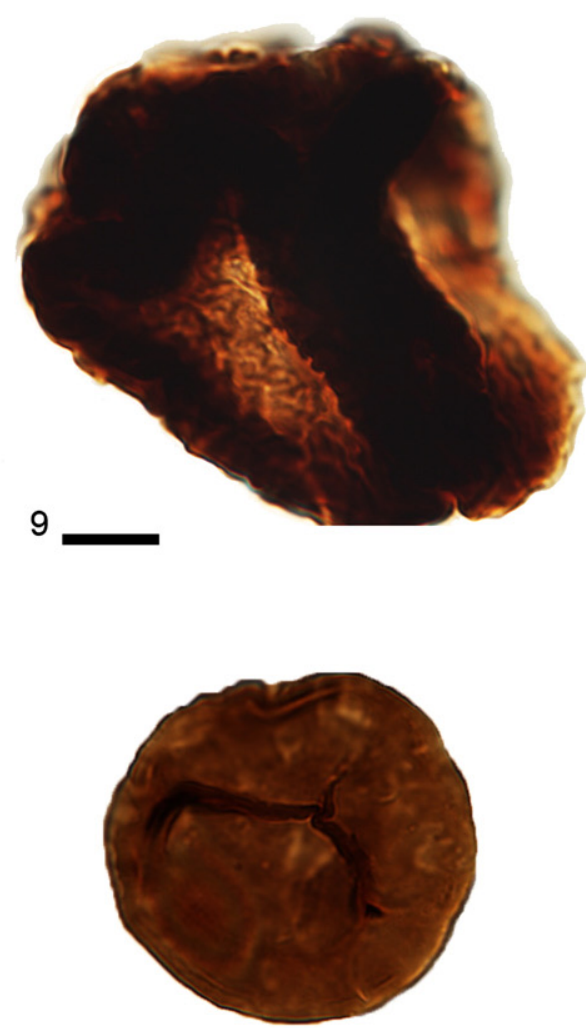

12

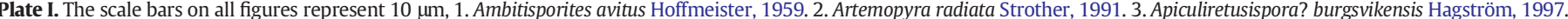

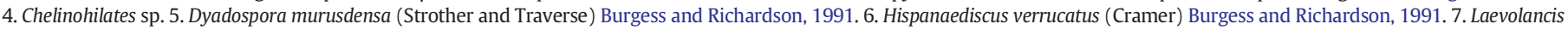

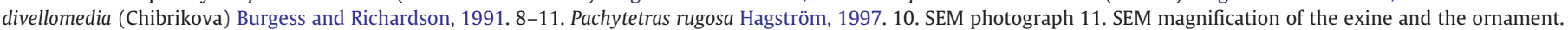
12. Retusotriletes goensis Lele and Streel, 1969. 


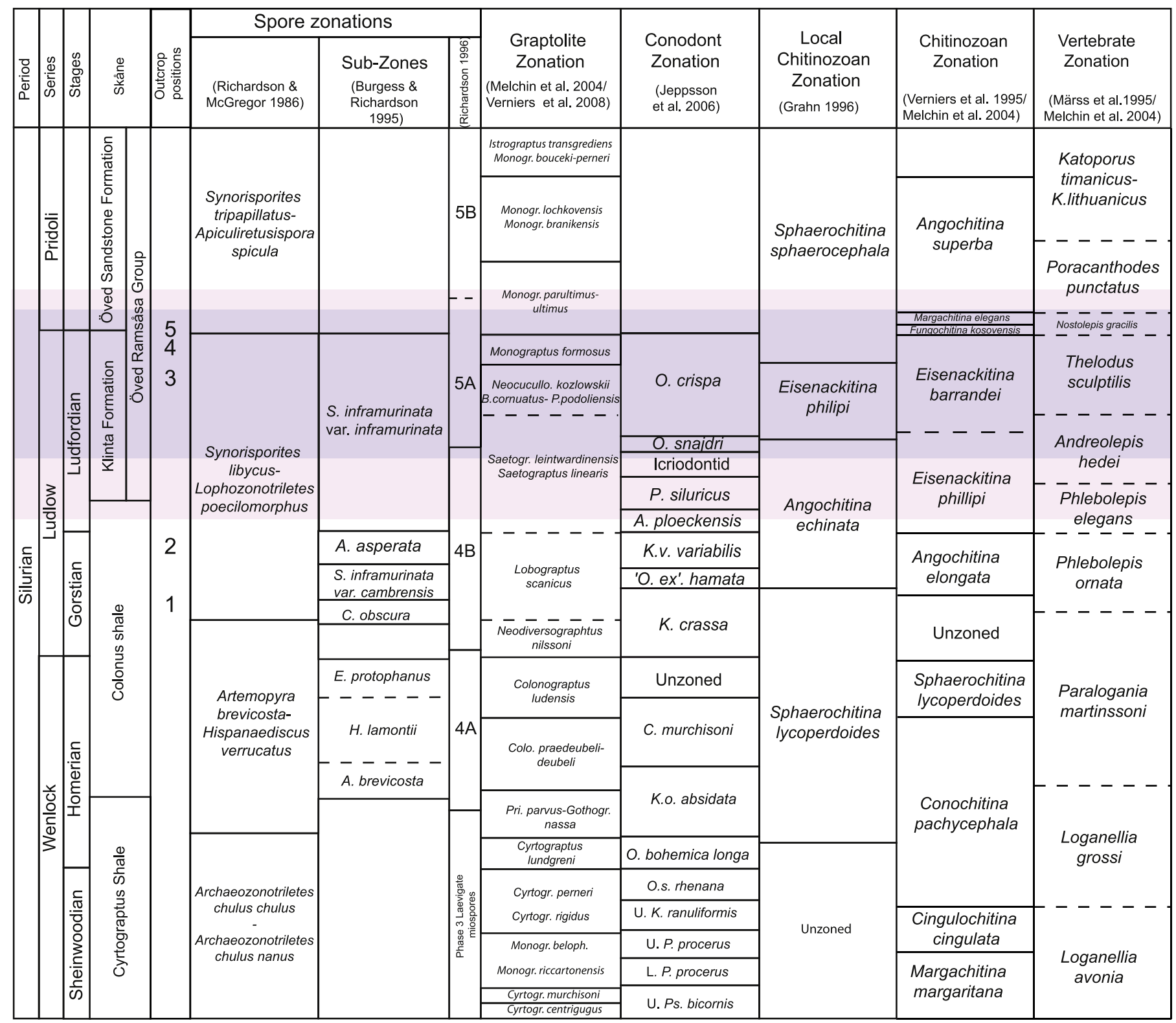
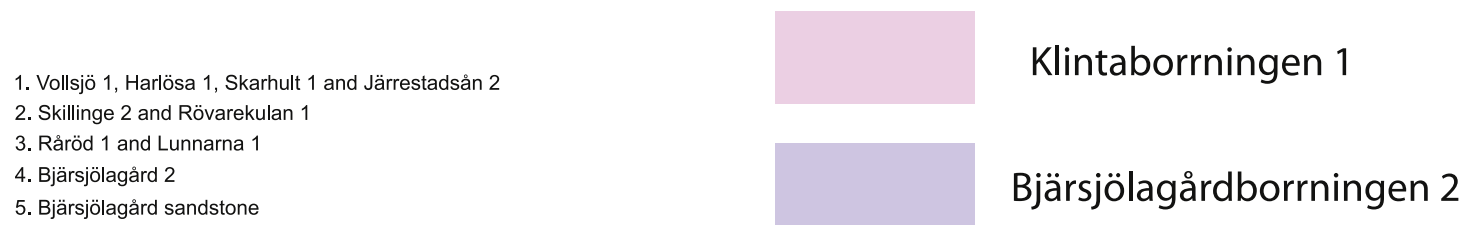

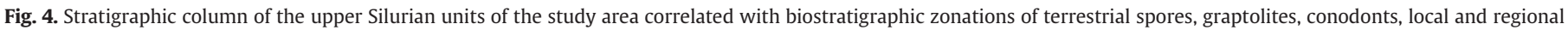
chitinozoans and vertebrates.

zone (Grahn, 1996). These assemblages are correlated to the Kockelella crassa conodont zone (Jeppsson et al., 2006).

The Colonus Shale in the Vollsjöån rivulet thus corresponds to the Chelinospora obscura and Stellatispora inframurinata var. cambrensis spore sub-zones of Burgess and Richardson (1995) within the base of the spore zone libycus-poecilomorphus of Richardson and McGregor (1986).

5.3.1.2. Harlösa 1. Grey to green mudstones are exposed along the Harlösabäcken rivulet, in places disrupted by micro-faults ( 6176740
N/408357 E). Here, four samples, A-D, were collected from a vertical exposure with a sample resolution of $0.5 \mathrm{~m}$ (Plate II: 1 ). Only three spores were identified in sample A and seven in sample C, whilst samples B and $\mathrm{D}$ were barren of spores (Table 3 ). The identified taxa include Laevolancis divellomedia, Laevolancis plicata, Tetrahedraletes medinensis and Tetrahedraletes grayii (Fig. 6). Chitinozoans occur in these samples but no other marine microfossils were identified. The section exposed at Harlösa 1 have been assigned to the Colonograptus colonus graptolite zone which in turn corresponds to the top of Sphaerochitina lycoperdoides chitinozoans zone (Grahn, 1996) and the Kockelella crassa conodont zone 


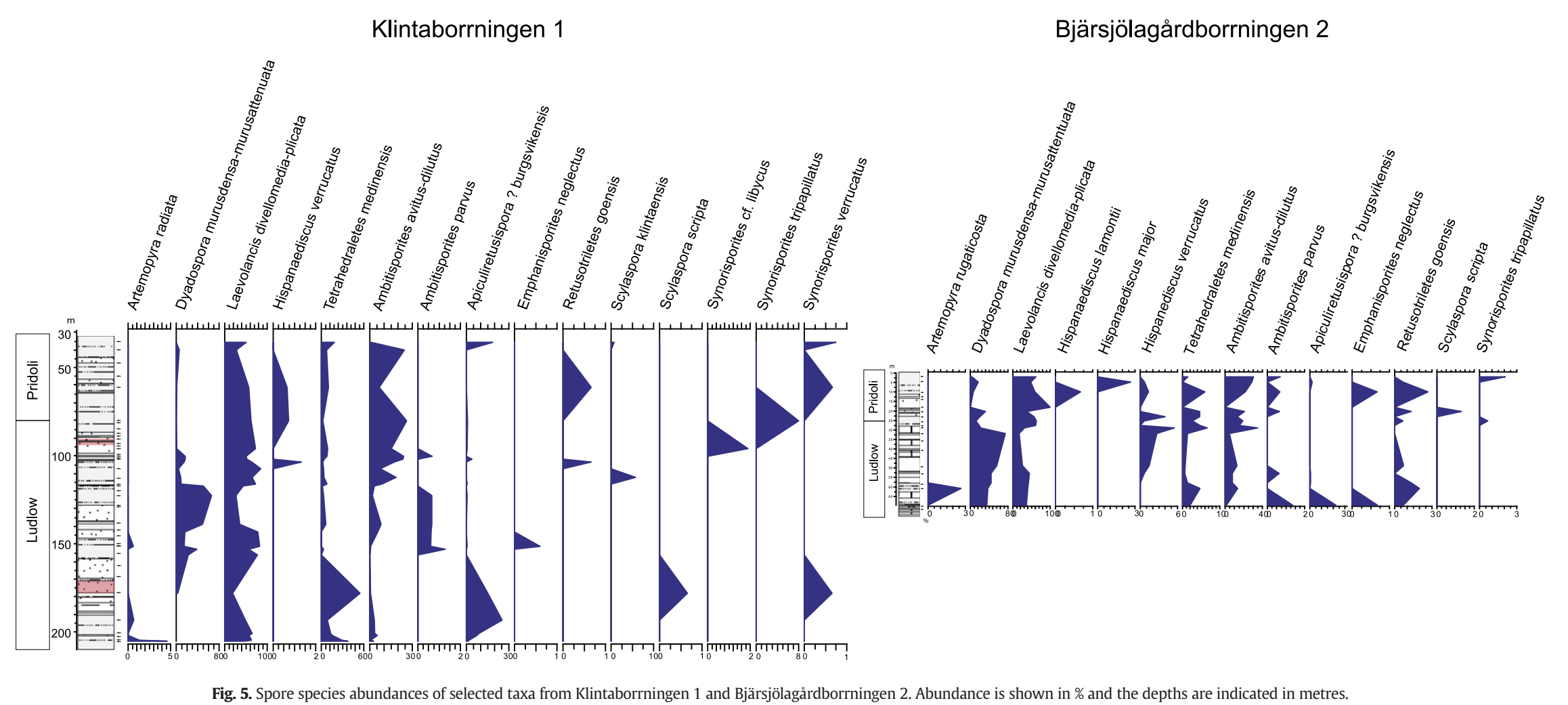

Fig. 5. Spore species abundances of selected taxa from Klintaborrningen 1 and Bjärsjölagårdborrningen 2. Abundance is shown in \% and the depths are indicated in metres. 


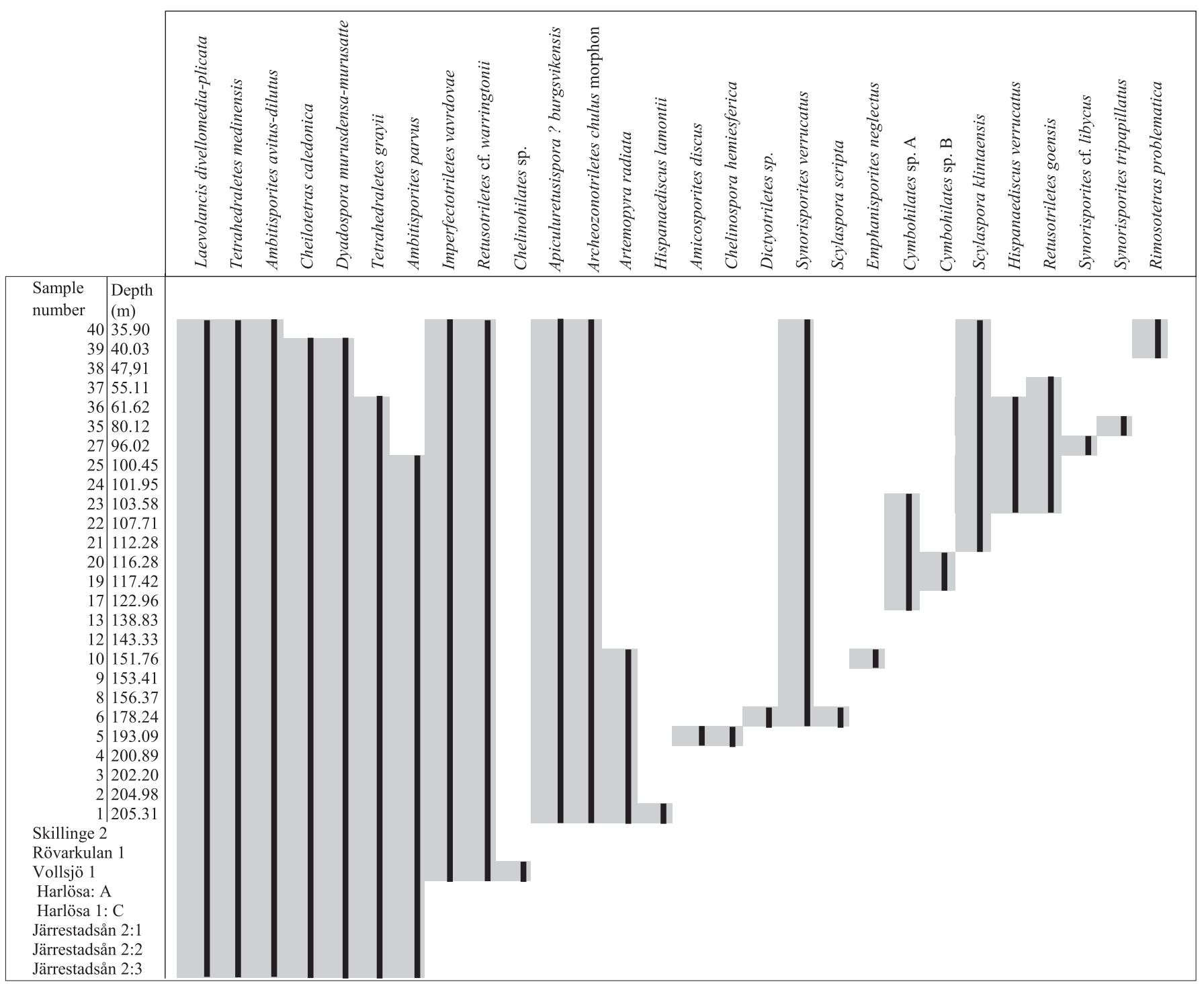

Fig. 6. Range chart of spores species identified in Klintaborrningen 1 and in the outcrop samples.

of Ludlow (Gorstian) age. The marine microfossil schemes further correspond to Chelinospora obscura and Stellatispora inframurinata var. cambrensis spore sub-zones within the base of the libycus-poecilomorphus spore zone.

5.3.1.3. Skarhult 1. This locality is situated in the proximity of the city of Eslöv ( $6185232 \mathrm{~N} / 398598 \mathrm{E}$ ). Silurian grey mudstones belonging to the Odarslöv Sandstone (lower-middle part of the Colonus Shale) are exposed at the bottom of the Bråån Creek. The exposure along the creek by the bridge was sampled. The sedimentary rocks at the Skarhult 1 locality are at some levels rich in fossils (Hede, 1919) and contain the earliest tentaculitid fauna in Skåne along with the assemblage identified in Röddinge (Larsson, 1979). No spores were found in this sample but phytodebris and minor occurrences of chitinozoans and scolecodont elements were encountered. The sedimentary rocks exposed at Skarhult 1 have previously been assigned to the Colonograptus colonus graptolite zone (Nilsson, 2002) and to the top of the Sphaerochitina lycoperdoides chitinozoan zone (Grahn, 1996) and the Kockelella crassa conodont zone of Ludlow (Gorstian) age (Jeppsson et al., 2006). This interval corresponds to the Chelinospora obscura and Stellatispora inframurinata var. cambrensis spore sub-zones within the base of the libycus-poecilomorphus zone.
5.3.1.4. Järrestadsån 2. At this locality, mudstones (light grey to green and dark grey to brown) of the Colonus Shale are exposed in the valley between Gärarp and Tommarp (6154334 N/453392 E). Three samples were collected from an exposed section along the small rivulet, Tommarpsån, in a meadow from a vertical section and with a sample resolution of $0.5 \mathrm{~m}$ (Plate II: $2-3$ ). In the lowermost sample (sample 1), only one specimen was identified (Tetrahedraletes medinensis) whilst sample 2 contains 37 spores dominated by T. medinensis. Sample 3 is rich in spores and is also dominated by T. medinensis together with other permanent tetrads such as Tetrahedraletes grayii. The composition of the miospore assemblage, highly dominated by permanent tetrads lacking envelope (Cheilotetras caledonica, T. medinensis and T. grayii) together with genera such as Laevolancis, Dyadospora and Ambitisporites suggests an early to mid Silurian age (Fig. 6). Minor occurrences of chitinozoans were found in sample number 2. Grahn (1996) assigned the sedimentary rocks of this locality to the Colonograptus colonus Zone of Ludlow (Gorstian) age (Fig. 3). In the terrestrial realm this corresponds to the Chelinospora obscura and Stellatispora inframurinata var. cambrensis spore sub-zones within the base of the libycus-poecilomorphus spore zone.

5.3.1.5. Skillinge 2: new locality. This locality has previously not been described. Sedimentary rocks consisting of grey mudstones representing 

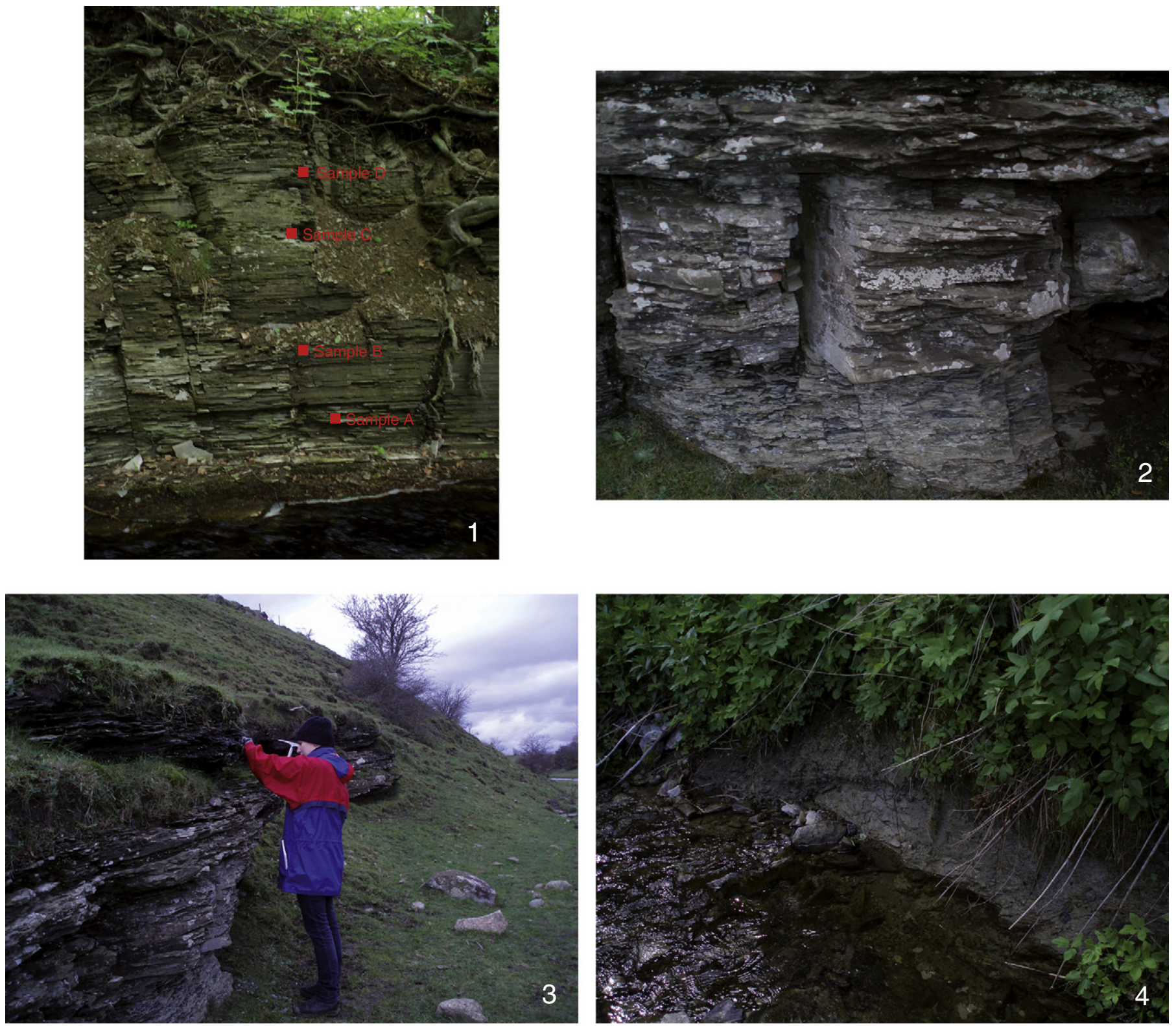

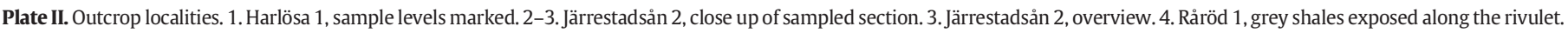

the top of the Colonus Shale are exposed along the beach northeast of Skillinge harbour (6148092 N/455184 E). One sample was collected from the loose slabs on the beach. In this sample, only two Dyadospora murusdensa spores were identified. Additionally, sparse marine microfossils such as scolecodont elements and chitinozoans were identified. The sedimentary rocks exposed at Skillinge 1 is in Grahn (1996) assigned to the Saetograptus chimaera graptolite zone corresponding to the lower part of the Angochitina echinata chitinozoan zone and the 'O. ex'. hamata to K.v. variabilis conodont zones of Ludlow (Gorstian) age (Grahn, 1996; Nilsson, 2002; Jeppsson et al., 2006).

This interval corresponds to the Apiculiretusispora? asperata spore subzone within the libycus-poecilomorphus zone (Fig. 3).

5.3.1.6. Rövarekulan 1. At this locality ( 6184014 N/405979 E), parts of the Colonus Shale is exposed in a narrow valley eroded by the Bråån Creek and the sedimentary rocks comprise light grey to light green siltstones and mudstones. Two samples were collected from the exposed section along the Bråån in the Rövarekulan nature reserve, one from the darker mudstone and the other from a siltstone lens. Only the siltstone sample yielded spores whilst the sample from the darker shale contains poorly preserved algae of unknown affinity. The spores identified include Laevolancis divellomedia and Tetrahedraletes medinensis (Fig. 6). Marine microfossils such as acritarchs, chitinozoans and scolecodont elements were further encountered. The succession at this locality belongs to the Saetograptus chimaera graptolite zone corresponding to the lower part of the Angochitina echinata chitinozoans zone and the 'O. ex'. hamata to K.v. variabilis conodont zones dated as Ludlow (Gorstian) (Grahn, 1996; Jeppsson et al., 2006). This interval corresponds to the spore subzone Apiculiretusispora? asperata within the libycus-poecilomorphus Zone (Fig. 3).

\subsubsection{Late Ludlow (Ludfordian)-Př́ídoli}

5.3.2.1. Lunnarna 1. Lunnarna 1 is located in the Ringsjö area close to the village of Snogeröd (6188674 N/406589 E). Here the succession consisting of grey to green mudstones is exposed in a canalized brook and one sample was collected from this locality. Only eight spores were identified in this single sample including the taxa Retusotriletes $\mathrm{cf}$. warringtonii, Laevolancis divellomedia and Laevolancis plicata. The low recovery of spores hampers a biostratigraphical assessment. No marine 
Table 3

Quantitative palynological data for the outcrop samples.

\begin{tabular}{|c|c|c|c|c|c|c|c|c|c|c|c|c|}
\hline Taxa & $\begin{array}{l}\text { Vollsjö } \\
1\end{array}$ & $\begin{array}{l}\text { Harlösa: } \\
\text { A }\end{array}$ & $\begin{array}{l}\text { Harlösa } \\
1: C\end{array}$ & $\begin{array}{l}\text { Järrestadsån } \\
2: 1 \text {. }\end{array}$ & $\begin{array}{l}\text { Järrestadsån } \\
2: 2 .\end{array}$ & $\begin{array}{l}\text { Järrestadsån } \\
\text { 2:3. }\end{array}$ & $\begin{array}{l}\text { Skillinge } \\
2\end{array}$ & $\begin{array}{l}\text { Rövarkulan } \\
1\end{array}$ & $\begin{array}{l}\text { Råröd } \\
1\end{array}$ & $\begin{array}{l}\text { Bjärsjölagård } \\
2: 1,65 \mathrm{~m}\end{array}$ & $\begin{array}{l}\text { Bjärsjölagård } \\
2: 1,45 \mathrm{~m}\end{array}$ & $\begin{array}{l}\text { Bjärsjölagård } \\
2: 0,5 \mathrm{~m}\end{array}$ \\
\hline Artemopyra radiata & & & & & & & & & 4 & & & \\
\hline Cheilotetras caledonica & & & & & & 3 & & & & & & \\
\hline Chelinohilates sp. & 8 & & & & & & & & 6 & & & \\
\hline Cymbohilates sp. A & & & & & & & & & 2 & & & \\
\hline Dyadospora murusattenuata & 1 & & & & & 3 & & & & & 2 & 3 \\
\hline Dyadospora murusdensa & 2 & & & & 1 & 9 & 1 & & & & & 6 \\
\hline Hispanaediscus verrucatus & & & & & & & & & & 4 & 11 & 12 \\
\hline Imperfectotriletes vavrdovae & 2 & & & & & & & & 7 & & 2 & 2 \\
\hline Laevolancis divellomedia & 109 & 1 & 3 & & & 11 & & 1 & 79 & 54 & 64 & 62 \\
\hline Laevolancis plicata & 15 & & 1 & & & 7 & & & 46 & 38 & 53 & 46 \\
\hline Pachytetras rugosa & & & & & & & & & & 6 & 8 & \\
\hline Rimosotetras problematica & & & & & & & & & & & & 1 \\
\hline Tetrahedraletes grayii & 2 & 1 & & 1 & 3 & 39 & & & 1 & 2 & 1 & 2 \\
\hline Tetrahedraletes medinensis & 17 & 1 & & 1 & 12 & 67 & & 1 & 14 & 5 & 4 & 1 \\
\hline Ambitisporites avitus & 2 & & & & & 3 & & & 2 & 9 & 20 & 18 \\
\hline Ambititsporites dilutus & & & & & & 5 & & & & & & \\
\hline Ambitisporites parvus & & & & & & 1 & & & & 4 & 4 & 2 \\
\hline $\begin{array}{l}\text { Apiculiretusispora? } \\
\text { burgsvikensis }\end{array}$ & & & & & & & & & & & 1 & \\
\hline Apiculiretusispora sp. B & & & & & & & & & & 1 & & \\
\hline Retusotriletes cf. warringtonii & 1 & & & & & & & & & & & 1 \\
\hline Number of specimens & 159 & 3 & 4 & 2 & 16 & 148 & 1 & 2 & 161 & 123 & 170 & 156 \\
\hline
\end{tabular}

microfossils were identified in this sample. The sedimentary rocks in Lunnarna 1 have, based on marine microfossils, been dated to late Ludlow and assigned to Saetograptus fritschi linearis-Saetograptus leintwardinensis graptolite zone corresponding to the top of the Angochitina echinata and the lower part of Eisenachitina philipi chitinozoan zone coeval with the Icriodontid to Ozarkodina crispa conodont zones.

This corresponds to Stellatispora inframurinata var. inframurinata spore sub-zone within the libycus-poecilomorphus zone (Fig. 3).

5.3.2.2. Råröd 1. This site is located in the proximity of the Stehag village (Fig. 2b) (6193826 N/402691 E). Here, Silurian light grey to green shales are exposed along a small rivulet from where one sample was taken. This sample is dominated by long ranging cosmopolitan spore species including, Laevolancis divellomedia, Laevolancis plicata and Tetrahedraletes medinensis. Additionally, Artemopyra radiata and the cryptospore Chelinohilates sp. were identified. The lack of biostratigraphically important species makes it difficult to determine the exact age of this sample. The sample is dominated by spores but, marine microfossils such as acritarchs, chitinozoans, graptolite fragments and scolecodonts are present in low relative abundances. The succession at Råröd 1 has been assigned to the Saetograptus fritschi linearis-Saetograptus leintwardinensis graptolite zone of Ludlow age which corresponds to the top of the Angochitina echinata and lower part of Eisenachitina philipi chitinozoan zone (Grahn, 1996; Fig. 4.). This corresponds to the Icriodontid to Ozarkodina crispa conodont zones (Jeppsson et al., 2006). The marine biota has been dated as Ludlow (Ludfordian) age. This corresponds to Stellatispora inframurinata var. inframurinata spore sub-zone within the libycus-poecilomorphus zone (Fig. 3).

5.3.2.3. Bjärsjölagård 2. Three samples from the old, partly water-filled, limestone quarry in Bjärsjölagård were collected (from the levels $0.5 \mathrm{~m}, 1.45 \mathrm{~m}$ and $1.65 \mathrm{~m}$ from the first ledge above the water level, Plate II: 4). All samples host rich and well-preserved spore assemblages and the dominant species are Laevolancis divellomedia and Laevolancis plicata, along with Ambitisporites avitus, Hispanaediscus verrucatus and Pachytetras rugosa. The latter species was described as being present in Ludfordian sedimentary rocks on Gotland (Hagström, 1997). Minor occurrences of scolecodont elements and chitinozoans were observed. The age of these units has, based on marine microfossils, been interpreted to late Ludlow-Př́dolí corresponding to the Sphaerochitina sphaerocephala chitinozoan zone (Grahn, 1996) and the Hindeodella wimani conodont fauna (Jeppsson, 1974).

This corresponds to the top of Stellatispora inframurinata var. inframurinata spore sub-zone within the top of the libycus-poecilomorphus zone (Fig. 3).

5.3.2.4. Bjärsjölagård sst. Sandstone sediments from Bjärsjölagård are exposed along a canalized brook from the quarry in a forested area east of the old limestone quarry (Plate II). The sedimentary rocks comprise heavily cemented, very hard quartz arenites with a sugary texture. One sample was collected from loose rocks along the brook in the forest $200 \mathrm{~m}$ from the old limestone quarry. In the palynological residue, a few acritarchs and 11 spores (only Tetrahedraletes grayii identified) were encountered representing the first microfossils ever found in this sandstone interval (Table 3). This sandstone corresponds to the siltstone/ sandstone unit encountered in the core of Bjärsjölagårdborrningen 2 in the interval $11.36-19.70 \mathrm{~m}$ (Fig. 3). The sandstone represents basal Přídoli, corresponding to the Synorisporites tripapillatus Apiculiretusispora spicula spore zone (Fig. 3). Interestingly, Tullberg (1882) noted possible plant remains in the same sandstone from adjacent outcrops.

\section{Discussion}

\subsection{Correlation of the studied drillcores}

The drillcores Klintaborrningen 1 and Bjärsjölagårdborrningen 2 cover Ludlow and the base of Přídolí where the latter core is shorter and corresponds to the upper part of the Klintaborrningen 1 core (Fig. 3). The lithology differs in the two cores; the sedimentary rocks in $\mathrm{K} 1$ are more siliciclastic with mudstone, siltstone and sandstone layers whereas B2 is more biogenic with carbonates and corals. The drillcores are correlated, based on the first appearance datum (FAD) of Synorisporites tripapillatus, where the middle part of $\mathrm{K} 1(80 \mathrm{~m})$ is correlated to the lower part of B2 (72-25 m) (Fig. 3). The upper part of K1 (80-35 $\mathrm{m})$ and the upper part of B2 (25-2 m) are correlated and assigned to the Synorisporites tripapillatus-Apiculiretusispora spicula Assemblage Zone of Richardson and McGregor (1986) with a Přídolí age. It needs to be emphasized that the presence of S. tripapillatus in itself 
cannot convincingly pin point a Přídolí age but rather the LudlowPřídoli transition. However, based on the correlation with the marine biostratigraphy a Přídolí age is most probable. The sedimentary rocks from the drillcores correlate to the succession exposed in the Bjärsjölagård quarry. The studied samples from Bjärsjölagård 2 are correlated to the Limestone interval occurring at c. $30 \mathrm{~m}$ in Bjärsjölagårdborrningen 2 of late Ludfordian age. The Bjärsjölagård Sandstone is correlated to the sandstone unit at c. 19-14 $\mathrm{m}$ in the drillcore B2 of Přídolí age (Fig. 3).

\subsection{Comparison with the marine biostratigraphical zonation schemes}

The age of the studied succession from the Bjärsjölagårdborrningen 2 , agrees well with previous studies on tentaculitids identified from the same drillcore (Larsson, 1979), and this is the only other microfossil group that has been used as a biostratigraphical tool in these drillcores. The spore zones brevicosta-verrucatus to libycus-poecilomorphus (Homerian-Ludfordian) coincide with the presence of the typical late Silurian tentaculitid species Lonchidium scanicum, Lonchidium ogmotum, Tentaculites hisingeri and Odessites portensis outlined in Larsson (1979). The sedimentary rocks assigned to the slightly younger spore zone tripapillatus-spicula of Přídolí age host the tentaculitid species Lonchidium groenwalli, Tentaculites scalaris, Lonchidium mobergi, Odessites lebiensis and Tentaculites loxus (Larsson, 1979). Among these, T. scalaris is known from upper Přídolí in the Ohesaare Beds of Estonia, whilst 0 . lebiensis is represented in the basal part of the Podlasian beds in Poland, i.e. the lower Př́dolí (Larsson, 1979) and these two species are confined to the interval 0-10.2 $\mathrm{m}$ in B2 and 39-57 $\mathrm{m}$ in $\mathrm{K} 1$.

Studies on other fossil groups such as conodonts (Jeppsson, 1974), and chitinozoans (Grahn, 1996), have been performed on coeval, exposed sedimentary rocks in Skåne. Jeppsson (1974) described conodonts from the Öved-Ramsåsa Group in Skåne and Grahn (1996) described late Silurian (late Wenlock-early Přídolí) chitinozoans from the Colonus Shale and the Öved-Ramsåsa Group from Skåne, Sweden. Grahn (1996) also erected a biostratigraphical zonation of chitinozoans from the late Silurian of Sweden and correlated it to biozonations of graptolites. However, correlations between the outcrop and drillcore successions have been based merely on lithology as the marine microfossils were only studied from the exposed sections due to the large sample size required (Jeppsson et al., 2006). The studied spore assemblages range from the top of the brevicosta-verrucatus Zone to the lower part of the tripapillatus-spicula Zone, corresponding to the conodont zones K. crassa up to at least Ozarkodina crispa (Fig. 4). The spore assemblages further correlate with the Neodiversographtus nilssoni graptolite zone up to at least the Monograptus parultimus-ultimus Zone and with the local chitinozoan zones Sphaerochitina lycoperdoides up to Sphaerochitina sphaerocephala (Fig. 4). The libycus-poecilomorphus spore zone coincides with the occurrence of the following polychaetan species of the family Ramphoprionidae; Protarabellites rectangularis, Protarabellites staufferi, Protarabellites triangularis and Ramphoprion gotlandensis described from the Bjärsjölagård Limestone Member of the Klinta Formation, Skåne (Eriksson, 2002).

\section{Depositional environment and the terrestrial ecosystem}

The general pattern that emerges when compiling all the studied successions and their palynological content is the shallowing upwards trend where the dark Colonus Shales grade into mudstones and subsequently lighter coloured carbonates. This shows a gradual change from anoxic, deep-water conditions to deposition in well-oxygenated marine ecosystems within the photic zone. Our interpretations are in accordance with results presented in Wigforss-Lange (2007) stating that the Klinta succession shows an upward transition from open marine to lagoonal environments whilst the Bjärsjölagård limestone has been interpreted as deposited in a coastal environment on a mixed carbonate-siliciclastic shelf in an open-marine setting with freshwater input (Nilsson, 2006).

However, within the marine carbonates, the terrestrial flora has left its signatures and substantial information about the terrestrial ecosystem can be deduced from the palynology also in the marine carbonates. We further interpret the sandstones in the top of the Bjärsjölagårdborrningen 2 (also exposed in the Bjärsjölagård quarry) as terrestrially deposited due to the dearth of marine microfossils but with presence of root fragments (Tullberg, 1882) indicative of a regolith formation. The plants responsible for the spore dispersal probably grew along distributary channels and their spores could spread by rivers and subsequently accumulated in the near-shore to off-shore environments of the inner shelf. Richardson (1996) argues that some spores can have been dispersed by the wind since some are below $25 \mu \mathrm{m}$ in size. However most of the specimens of this study range up to $60 \mu \mathrm{m}$ and are thus too heavy for wind dispersal. As most spores in this study exceed $30 \mu \mathrm{m}$, they were most probably transported by water into the basin.

The assemblage is numerically dominated by cryptospores, mostly long-ranging cosmopolitan species making a biostratigraphic assessment difficult. The assemblages are moderately diverse with the same diversity of cryptospores and trilete spores. The studied assemblages are similar in composition to the coeval Gotland assemblage from the Burgsvik Beds described in Hagström (1997). However the late Silurian spore assemblages of Skåne reveal an endemic flora dominated by liverwort-like embryophytes and early vascular plants.

\section{Conclusions and summary}

This palynological study from Skåne, Sweden includes two drillcore successions, Klintaborrningen 1 and Bjärsjölagårdborrningen 2, comprising 205 and $75 \mathrm{~m}$ respectively. Additionally, 10 exposures were sampled for palynology, of which all but one contained spores.

In summary, the study reveals rich and well preserved late Silurian spore assemblages. In total (including drillcore and outcrop sections) 36 spore species belonging to 21 genera were identified. The cryptospores (produced by now extinct, primitive land plants) and trilete spores (produced by vascular plants) are represented by 18 species each.

The quantitatively dominating species are the cryptospores Laevolancis plicata followed by Laevolancis divellomedia. The organic matter is highly dominated by spores and plant phyto-debris but marine microfossils, such as prasinophytes, acritarchs, chitinozoans and scolecodont elements occur in some samples.

Although the recovery of terrestrial palynomorphs is poor in some of the outcrop samples, these results are important as they provide the first evidence of terrestrial spores in these successions.

The studied interval spans the lower Ludlow (Gorstian) to Přídolí. We have based the age assessments on a combination of previously published marine microfossil and, for the younger successions, on spore zonations. Importantly the marine microfossil zonation has been tied to spore assemblages of this study, linking the marine and terrestrial succession of these late Silurian ecosystems.

\section{Acknowledgements}

This research is funded by the Royal Physiographic Society in Lund, the Royal Swedish Academy of Sciences through the Knut and Alice Wallenberg Foundation and by the Swedish Research Council (VR) under grant LUCCI (Lund University Carbon Cycle Centre). Two anonymous referees are thanked for constructive criticism improving this manuscript. Philippe Steemans and John Richardson are acknowledged for valuable assistance in taxonomical identifications of spores. We further thank J. Wigforss-Lange for contributing information about the drill core material. Russ Harms GeoLab Ltd. is thanked for palynological processing and Mike Pole for the language review. 


\section{References}

Bergström, S.M., Huff, W.D., Koren, T., Larsson, K., Ahlberg, P., Kolata, D.R., 1999. The 1997 core drilling through Ordovician and Silurian strata at Röstånga, S. Sweden: preliminary stratigraphic assessment and regional comparison. GFF 121, $127-135$.

Burgess, N.D., Richardson, J.B., 1991. Silurian cryptospores and miospores from the type Wenlock area, Shropshire, England. Palaeontology 34, 601-628.

Burgess, N.D., Richardson, J.B., 1995. Late Wenlock to Early Přídolí cryptospores and miospores from south and southwest Wales, Great Britain. Palaeontographica 236, $1-44$.

Cocks, L.R.M., Torsvik, T.H., 2002. Earth geography from 500 to 400 million years ago: a faunal palaeomagnetic review. J. Geol. Soc. Lond. 159, 631-644.

Eriksson, M., 2001. Silurian ramphoprionid polychaetes from Gotland, Sweden. J. Paleontol. 75, 993-1015.

Eriksson, M., 2002. The palaeobiogeography of Silurian ramphoprionid polychaete annelids. Palaeontology 45, 985-996.

Eriksson, M.E., Bergman, C.F., Jeppsson, L., 2004. Silurian scolecodonts. Rev. Palaeobot. Palynol. 131, 269-300.

Grahn, Y., 1996. Upper Silurian (Upper Wenlock-Lower Př́ídolí) Chitinozoa and Biostratigraphy of Skåne, Southern Sweden. GFF 118 (4), 237-250.

Gray, J., Laufeld, S., Boucot, A.J., 1974. Silurian trilete spores and spore tetrads from Gotland: their implications for land plant evolution. Science 185, 260-263.

Hagström, J., 1997. Land-derived palynomorphs from the Silurian of Gotland, Sweden. GFF 119, 301-316

Hagström, J., Mehlqvist, K., 2012. The dawn of terrestrial ecosystems on Baltica: first report on land plant remains and arthropod coprolites from the Upper Silurian of Gotland, Sweden. Palaeogeogr. Palaeoclimatol. Palaeoecol. 317-318C, $162-170$.

Hede, J.E., 1919. Om en förekomst av colonusskiffer vid Skarhult i Skåne. Geol. Fören. Stockh. Förh. 41, 113-160.

Hoffmeister, W.S., 1959. Lower Silurian plant spores from Libya. Micropaleontology 5, 331-334.

Jaeger, H., 1991. Neue Standard-Graptolithen Zonenfolge nach der "Großen Krise" an der Wenlock/Ludlow-Grenze (Silur). Neues Jahrb. Mineral. Geol. Palaeontol. Abh. 182, 303-354.

Jeppsson, L., 1974. Aspects of Late Silurian conodonts. Fossils Strata 6, 1-54 (Oslo, Pls. 1-12).

Jeppsson, L., 2005. Conodont-based revisions of the Late Ludfordian on Gotland, Sweden. GFF 127, 273-282.

Jeppsson, L., Laufeld, S., 1986. The Late Silurian Öved-Ramsåsa Group in Skåne, southern Sweden. Sver. Geol. Unders. 58, 1-45 (Ca).

Jeppsson, L., Eriksson, M.E., Calner, M., 2006. A latest Llandovery to latest Ludlow highresolution biostratigraphy based on the Silurian of Gotland-a summary. GFF 128 , 109-114.

Jeppsson, L., Talent, J.A., Mawson, R., Simpson, A.J., Andrew, A.S., Calner, M., Whitford, D.J., Trotter, J.A., Sandström, O., Caldon, H.-J., 2007. High-resolution Late Silurian correlations between Gotland, Sweden, and the Broken River region, NE Australia: lithologies, conodonts and isotopes. Palaeogeogr. Palaeoclimatol. Palaeoecol. 245, $115-137$.

Larsson, K., 1979. Silurian tentaculitids from Gotland and Scania. Fossils Strata 11, 1-180.

Le Hérissé, A., 1989. Acritarches et kystes d'algues Prasinophycées du Silurien de Gotland, Suède. Palaeontogr. Ital. 76, 57-302.

Le Hérissé, A., Dorning, K.J., Mullins, G.L., Wicander, R., 2009. Global patterns of organicwalled phytoplankton biodiversity during the late Silurian to earliest Devonian. Palynology 33 (1), 25-75.

Lele, K.M., Streel, M., 1969. Middle Devonian (Givetian) plant microfossils from Goé (Belgium). Ann. Soc. Geol. Belg. 92, 89-121.

Märss, T., Fredholm, D., Talimaa, V., Turner, S., Jeppsson, L., Nowlan, G.S., 1995. Silurian vertebrate biozonal scheme. In: Lelievre, H., Wenz, S., Blieck, A., Cloutier, R. (Eds.), Premiers vertebrés et vertebrés inférieurs. Géobios, 19, pp. 369-372.

Mehlqvist, K., 2009. The Spore Record of Early Land Plants from Upper Silurian Deposits in Klinta 1 Well, Skåne, Sweden. (MSc thesis) Department of Geology, Lund University, Sweden.

Mehlqvist, K., Vajda, V., Steemans, P., 2012. Early land plant spore assemblages from the Late Silurian of Skåne, Sweden. GFF 134, 133-144.
Melchin, M.J., Cooper, R.A., Sadler, P.M., 2004. The Silurian period. In: Gradstein, F.M., Ogg, J.G., Smith, A.G. (Eds.), A Geologic Time Scale 2004. Cambridge University Press, Cambridge, pp. 188-201.

Moore, G.T., Jacobson, S.R., Ross, C.A., Hayashida, D.N., 1994. A paleoclimate simulation of the Wenlockian (Late Early Silurian) world using a general circulation model with implications for early land plant paleoecology. Palaeogeogr. Palaeoclimatol. Palaeoecol. $110,115-144$.

Nielsen, A.T., 2004. Ordovician sea level changes: a Baltoscandian perspective. In: Webby, B.D., Paris, F., Droser, M., Percival, I. (Eds.), The Great Ordovician Diversification Event. Columbia University Press, New York, pp. 84-93.

Nilsson, A., 2002. Early Ludlow (Silurian) Graptolites from Skåne, southern Sweden. (MSc thesis) Lund University, Sweden.

Nilsson, S., 2006. Sedimentary Facies and Fauna of the Late Silurian Bjärsjölagård Limestone Member (Klinta Formation), Skåne, Sweden. (MSc thesis), 195 (25).

Richardson, J.B., 1996. Lower and middle Palaeozoic records of terrestrial palynomorphs. In: Jansonius, J., McGregor, D.C. (Eds.), Palynology: Principles and Applications, vol. 2. American Association of Stratigraphic Palynologists Foundation. Publishers Press, Salt Lake City, UT, pp. 555-574.

Richardson, J.B., Edwards, D., 1989. Sporomorphs and plant megafossils. In: Holland, C.H. Bassett, M.G. (Eds.), A Global Standard for the Silurian System. National Museum of Wales, Cardiff, Geological Series, 9, pp. 216-226.

Richardson, J.B., Lister, T.R., 1969. Upper Silurian and Lower Devonian spore assemblages from the Welsh Borderland and South Wales. Palaeontology 12, 201-252.

Richardson, J.B., McGregor, D.C., 1986. Silurian and Devonian spore zones of the Old Red Sandstone continent and adjacent regions. Geol. Sur. Can. Bull. 364, 1-73.

Richardson, J.B., Rodriguez, R.M., Sutherland, S.J.E., 2001. Palynological zonation of Mid-Palaeozoic sequences from the Cantabrian Mountains, NW Spain: implications for inter-regional and interfacies correlation of the Ludford/Přídolí and Silurian/ Devonian boundaries, and plant dispersal patterns. Bull. Nat. Hist. Mus. Lond. (Geol.) 57, 115-162.

Rubinstein, C., Steemans, P., 2002. Miospore assemblages from the Silurian-Devonian boundary, in borehole A1-61, Ghadamis Basin, Libya. Rev. Palaeobot. Palynol. 118 397-421.

Scotese, C.R., 2003. PALEOMAP project. http://www.scotese.com/.

Steemans, P., 1996. Palynology of the Ludlovian Burgsvik Formation of Gotland, Sweden. Abstract IX IPC Meeting, Houston, Texas, USA, p. 151 (June 23-28).

Strother, P.K., 1991. A classification for the cryptospores. Palynology 15, 4-20.

Tullberg, S.A., 1882. Beskrifning till Kartbladet Övedskloster. Sver. Geol. Unders. 86, 1-50 (Aa).

Vergoossen, J.M.J., 1999. Late Silurian fish microfossils from Helvetesgraven, Skåne (southern Sweden) (I). Geol. Mijnb. 78, 267-280.

Vergoossen, J.M.J., 2002a. Late Silurian fish microfossils from Ramsåsa, locality H, Scania, southern Sweden, with some remarks on the body zonation scheme used in thelodont studies. Scr. Geol. 123, 41-69.

Vergoossen, J.M.J., 2002b. Late Silurian fish microfossils from Klinta and Rinnebäcks Bro (Scania, southern Sweden), with some remarks on the morphology of Nostolepis striata trunk scales. Scr. Geol. 123, 71-92.

Vergoossen, J.M.J., 2003. First record of fish microfossils from Ramsåsa, site C, Skåne, southern Sweden. Scr. Geol. 126, 1-78.

Vergoossen, J.M.J., 2004. Fish microfossils from Ramsåsa, site E, Scania, southern Sweden (mid Palaeozoic). Scr. Geol. 127, 1-70.

Verniers, J., Maletz, J., Kř́iž, J., Žigaitè, Ž., Paris, F., Shönlaub, H.P., Wrona, R., 2008. Silurian. In: McCann, T. (Ed.), The Geology of Central Europe, Precambrian and Palaeozoic, 1 784. The Geological Society of London, pp. 249-302 (Bath).

Wellman, C.H., 1993. A land plant microfossil assemblage of Mid Silurian age from the Stonehaven Group, Scotland. J. Micropalaeontol. 12, 47-66.

Wellman, C.H., Richardson, J.B., 1993. Terrestrial plant microfossils from Silurian inliers of the Midland Valley of Scotland. Palaeontology 36, 155-193.

Wellman, C.H., Habgood, K., Jenkins, G., Richardson, J.B., 2000. A new plant assemblage (microfossil and megafossil) from the Lower Old Red Sandstone of the AngloWelsh Basin: its implications for the palaeoecology of early terrestrial ecosystem. Rev. Palaeobot. Palynol. 109, 161-196.

Wigforss-Lange, J., 1999. Carbon isotope ${ }^{13} \mathrm{C}$ enrichment in Upper Silurian (Whitcliffian) marine calcareous rocks in Scania, Sweden. GFF 121, 273-279.

Wigforss-Lange, J., 2007. Tidal facies in the Upper Silurian Öved Ramsåsa Group of Scania, Sweden: linkages of radial and cerebroid ooids and evaporite tracers to subtidal lagoonal environment. GFF 129, 8-15. 